William \& Mary Law School

William \& Mary Law School Scholarship Repository

Faculty Publications

Faculty and Deans

2-2010

\title{
The Restrictive Ethos in Civil Procedure
}

A. Benjamin Spencer

spencer@wm.edu

Follow this and additional works at: https://scholarship.law.wm.edu/facpubs

Part of the Civil Procedure Commons, Courts Commons, and the Dispute Resolution and Arbitration Commons

Repository Citation

Spencer, A. Benjamin, "The Restrictive Ethos in Civil Procedure" (2010). Faculty Publications. 1980. https://scholarship.law.wm.edu/facpubs/1980

Copyright c 2010 by the authors. This article is brought to you by the William \& Mary Law School Scholarship Repository.

https://scholarship.law.wm.edu/facpubs 


\title{
Essay
}

\section{The Restrictive Ethos in Civil Procedure}

\author{
A. Benjamin Spencer* \\ "The courts are established to administer justice, and you \\ cannot have justice if justice is constantly being thwarted \\ and turned aside or delayed by a labyrinth of technical \\ entanglements."
}

Those of us who study civil procedure are familiar with the notion that federal civil procedure under the 1938 Rules was generally characterized by a "liberal ethos," meaning that it was originally designed to promote open access to the courts and to facilitate a resolution of disputes on the merits. ${ }^{2}$ Most of us are also aware of the fact that the reality of procedure is not always access-promoting or fixated on merits-based resolutions as a priority. Indeed, I would say that a "restrictive ethos" prevails in procedure today, with many rules being developed, interpreted, and applied in a manner that frustrates the

* Associate Professor of Law, Washington \& Lee University School of Law. I would like to thank those who were able to give helpful comments on the piece, especially Stephen Burbank, Richard Marcus, Laurence Solum, Laurens Walker, and Lonny Hoffman. I would also like to thank the participants in a presentation of this piece at the University of Illinois College of Law and at the DePaul University College of Law.

1 Rules of Civil Procedure for the District Courts of the United States: Hearing on H.R. 8892 Before the H. Comm. on the Judiciary, 75th Cong. 2 (1938) (statement of Homer Cummings, Att'y Gen. of the United States).

2 Richard L. Marcus, The Revival of Fact Pleading Under the Federal Rules of Civil Procedure, 86 Colum. L. Rev. 433, 439 (1986) ("Sobered by the fate of the Field Code, Dean Clark and the other drafters of the Federal Rules set out to devise a procedural system that would install what may be labelled the 'liberal ethos,' in which the preferred disposition is on the merits, by jury trial, after full disclosure through discovery.").

February 2010 Vol. 78 No. 2 
ability of claimants to prosecute their claims and receive a decision on the merits in federal court. ${ }^{3}$ In this Essay, after discussing some of the familiar components of the liberal ethos of civil procedure, I hope to set forth some of the aspects of federal civil procedure that reflect the restrictive ethos, following up with some thoughts on whether a dialectical analysis ${ }^{4}$ can help us understand the nature of the relationship between civil procedure's liberal and restrictive components.

\section{The Liberal Ethos}

The liberal ethos in civil procedure generally refers to those aspects of federal procedure that tend to promote access and meritsbased or accurate resolutions of civil disputes. ${ }^{5}$ That the Federal Rules were originally designed to promote access cannot be denied. The very notion of uniformity itself was an innovation designed to make the civil justice system more accessible to litigants. ${ }^{6}$ Also promoting the vision of open access espoused by the drafters was the introduction of simplified "notice pleading," which was designed to minimize greatly the number of cases dismissed on the pleadings.? With notice pleading replacing the cumbersome and "archaic factpleading $[, \mathrm{m}]$ ore people with legal grievances could gain entry into the system." 8 In many respects, the commitment to access endures; for example, the current post-1993 version of Rule 11-with its safe-harbor provision, emphasis on deterrence, and allowance for innovative legal arguments-was meant to complement simplified pleading by

3 I have noted the advent of a restrictive ethos in civil procedure in a previous writing. A. Benjamin Spencer, Plausibility Pleading, 49 B.C. L. Rev. 431, 479-83 (2008) (suggesting that a move away from notice pleading represented "the latest and perhaps final chapter in a long saga that has moved the federal civil system from a liberal to a restrictive ethos").

4 By dialectical analysis I mean an attempt to resolve the apparent contradictions between the components of the liberal ethos and the restrictive ethos to determine whether there is indeed a cooperative relationship between the two that can be understood as their synthesis.

5 See id. at 479.

6 A uniform nationwide system of procedure facilitated the development of litigators who could handle cases across the country, which in turn made it a much simpler matter for party litigants to retain competent counsel to represent their cause in the federal courts. Uniformity likely reduced the costs of federal litigation (at least initially), given that less time and effort had to be spent identifying applicable local procedural rules or retaining a local specialist who could help navigate those rules.

7 Conley v. Gibson, 355 U.S. 41, 47-48 (1957).

8 Eric K. Yamamoto, Efficiency's Threat to the Value of Accessible Courts for Minorities, 25 HARv. C.R.-C.L. L. REv. 341, 356-57 (1990). Recent developments on the pleading frontwhich call into question the idea of notice pleading and portend an era of more scrutinous review of pleadings-are discussed below in Part II as an element of the restrictive ethos. 
ensuring truthful allegations without deterring litigants from asserting what some may view as tenuous claims. ${ }^{9}$

The innovation of modern discovery ushered in by the rules further promoted access by enabling plaintiffs to initiate their claims without having to have full and complete information. Relatedly, delaying the test of the factual sufficiency of one's claim until after discovery is completed ${ }^{10}$ is supposed to give plaintiffs sufficient ability to investigate their claims under the aegis of the courts rather than prior to filing. Liberal joinder rules, as well as the class-action device, have promoted access by enabling parties with substantially related claims to prosecute together claims that they might otherwise have been unable to sustain individually. ${ }^{11}$

That the Federal Rules were originally imbued with a clear preference for merits-based, accurate resolutions of disputes is also clear. Simplified pleading ${ }^{12}$ and broad discovery ${ }^{13}$ were designed to promote resolution of disputes on the substantive merits as opposed to proce-

9 See 2 James Wm. Moore et al., Moore’s Federal Practice § 11.03 (3d ed. 2009) ("The 1993 amendments . . clarified and liberalized the standard for complying with Rule 11.").

10 This postponement of judgment day until after discovery is facilitated in part by Rule 56(f), which provides:

If a party opposing the motion shows by affidavit that, for specified reasons, it cannot present facts essential to justify its opposition, the court may:

(1) deny the motion;

(2) order a continuance to enable affidavits to be obtained, depositions to be

taken, or other discovery to be undertaken; or

(3) issue any other just order.

FED. R. Civ. P. 56(f). It must be noted, however, that to the extent plaintiffs are required to offer specific facts prior to discovery under the rule of Bell Atlantic Corp. v. Twombly, $127 \mathrm{~S}$. Ct. 1955, 1964-65 (2007), and Ashcroft v. Iqbal, 129 S. Ct. 1937, 1949-50 (2009)-the Supreme Court's most recent pleading decisions - this traditional allowance may be eroding. Twombly's and Iqbal's contribution to the restrictive ethos is discussed below. See infra notes 46-49, 82-86 and accompanying text.

11 See Phillips Petroleum Co. v. Shutts, 472 U.S. 797, 809 (1985) ("[T]his lawsuit involves claims averaging about $\$ 100$ per plaintiff; most of the plaintiffs would have no realistic day in court if a class action were not available."); Deposit Guar. Nat'l Bank v. Roper, 445 U.S. 326, 338 (1980) ("The use of the class-action procedure for litigation of individual claims may offer substantial advantages for named plaintiffs; it may motivate them to bring cases that for economic reasons might not be brought otherwise."). Further, requiring plaintiffs to opt-out rather than opt-in for damages in class actions facilitates access because plaintiffs in such cases with meager individual claims would otherwise be much less likely to participate in and enjoy the fruits of a class-action suit. Benjamin Kaplan, Continuing Work of the Civil Committee: 1966 Amendments of the Federal Rules of Civil Procedure (I), 81 HARv. L. Rev. 356, 397-98 (1967) ("[R]equiring the individuals affirmatively to request inclusion in the lawsuit would result in freezing out the claims of people-especially small claims held by small people-who for one reason or another, ignorance, timidity, unfamiliarity with business or legal matters, will simply not take the affirmative step.").

12 Swierkiewicz v. Sorema N.A., 534 U.S. 506, 514 (2002) ("The liberal notice pleading of 
dural technicalities. ${ }^{14}$ Liberal amendment rules permit parties to cure errors or omissions by amending their pleadings to add claims, defenses, or parties as necessary. ${ }^{15}$ The motion for judgment as a matter of law, ${ }^{16}$ the motion for new trial, ${ }^{17}$ and the motion for relief from judgment ${ }^{18}$ each provide litigants with an opportunity to seek a just, accurate resolution of their cause where the conclusion of the jury seems clearly inconsistent with the truth. Judicial discretion is rooted in the concern that disputes be resolved on their merits rather than procedural technicalities, resulting in a group of civil rules that permit judges to exercise significant discretion in the interest of justice. ${ }^{19}$ The disinclination of courts toward default judgments ${ }^{20}$ further indicates the preference for merits-based judgments over those obtained through procedural technicalities. ${ }^{21}$

Rule 8(a) is the starting point of a simplified pleading system, which was adopted to focus litigation on the merits of a claim.").

13 Jeffrey W. Stempel, Politics and Sociology in Federal Civil Rulemaking: Errors of Scope, 52 Ala. L. Rev. 529, 535-36 (2001) (“' Fishing expeditions' were to be allowed in the interests of developing facts in a relatively efficient way so that legal disputes could be determined in light of maximum factual information."); Stephen N. Subrin, Fishing Expeditions Allowed: The Historical Background of the 1938 Federal Discovery Rules, 39 B.C. L. REv. 691, 697-700 (1998); see also Hickman v. Taylor, 329 U.S. 495, 507 (1947) ("Mutual knowledge of all the relevant facts gathered by both parties is essential to proper litigation."); In re Sealed Case No. 98-3077, 151 F.3d 1059, 1069 (D.C. Cir. 1998) ("An overriding interest in the revelation of truth creates a need for free and open access to evidence ...."). By not making admissibility as evidence the standard for discoverability, and not requiring leave of the court to take depositions (both a result of the 1946 amendments to the Federal Rules), discovery was broadened beyond its initial scope. See Subrin, supra, at 736-37. The 1970 amendments went further in that direction by making insurance policies discoverable, eliminating the good-cause requirement for document production, permitting the discovery of expert witnesses and their supporting materials, and providing sanctions for noncompliance with one's discovery obligations. See Stempel, supra, at 540-41.

14 To reinforce the notice-pleading standard, Rule 8(e) indicates: "Pleadings must be construed so as to do justice." Fed. R. Civ. P. 8(e).

15 Fed. R. Civ. P. 15(a)(2) (providing that courts "should freely give leave [to amend pleadings] when justice so requires").

16 Fed. R. Civ. P. 50.

17 FED. R. Civ. P. 59.

18 Fed. R. Civ. P. 60.

19 Jay Tidmarsh \& Roger H. Trangsrud, Complex Litigation: Problems in Advanced Civil Procedure 6-7 (2002); see, e.g., Fed. R. Civ. P. 15 (delineating the conditions under which a court may allow a party to amend or supplement its pleadings); 28 U.S.C. § 1404 (2006) (permitting a court to transfer a civil action to another venue "in the interest of justice").

20 See, e.g., Lewis v. Lynn, 236 F.3d 766, 767 (5th Cir. 2001) (per curiam) (“[D]efault judgments are a drastic remedy, not favored by the Federal Rules and resorted to by courts only in extreme situations."); Katzson Bros. v. EPA, 839 F.2d 1396, 1399 (10th Cir. 1988) (stating "default judgments are not favored by courts").

21 See Pulliam v. Pulliam, 478 F.2d 935, 936 (D.C. Cir. 1973) (noting that in the context of a 
To the above-mentioned attributes of access and accuracy I would add another value to which the Federal Rules have generally aspired: the promotion of private efficiency and inexpensiveness. Indeed, a core value embodied in much of procedural law is the promotion of the efficient and inexpensive resolution of disputes between parties. ${ }^{22}$ Notice pleading permits litigants to assert claims without incurring the delay and expense that would accompany an obligation to plead detailed facts. ${ }^{23}$ The obligation under Rule 12 to consolidate or waive certain preliminary procedural challenges is at least intended to prevent dilatory tactics to some extent. ${ }^{24}$ Initial disclosures-added to the Rules in 1993 - were designed to save litigants the cost and hassle of having to pry such information from their adversaries, ${ }^{25}$ while the compelled-discovery system in general, coupled with the American rule requiring responding parties to cover their own discovery expenses, permits plaintiffs to have formal access ${ }^{26}$ to relevant information from defendants without ordinarily having to cover the expense of production. ${ }^{27}$

In shaping the scope of an action, the broad joinder rules ${ }^{28}$ are designed to permit the action to be crafted in a way that permits most related claims to be litigated together, an innovation away from the

default judgment "a court should liberally allow relief under" Rule 60(b) because "a resolution on the merits is preferable to a judgment by default").

22 FED. R. Civ. P. 1 (establishing that the Federal Rules "should be construed and administered to secure the just, speedy, and inexpensive determination of every action and proceeding").

23 Cf. 5 Charles Alan Wright \& Arthur R. Miller, Federal Practice and ProCEDURE: Civil $\S 1202$ (3d ed. 2004) ("The relevant facts may be determined by discovery. . . . The only function left to be performed by the pleadings alone is that of notice." (footnote omitted)).

24 See Fed. R. Civ. P. 12(g)-(h).

25 See FED. R. Civ. P. 26 advisory committee's notes to 1993 amendments ("[T]he experience of the few state and federal courts that have required pre-discovery exchange of core information such as is contemplated in Rule 26(a)(1) indicates that savings in time and expense can be achieved ....").

26 The term "formal access" is used here in distinction from "practical access," with the former concept reflecting the provision in the rules for the compelled exchange of all relevant information and the latter describing the ability actually to obtain desired materials through discovery.

27 See Oppenheimer Fund, Inc. v. Sanders, 437 U.S. 340, 358 (1978) (noting that "[u]nder [discovery] rules, the presumption is that the responding party must bear the expense of complying with discovery requests"). Recent electronic-discovery reforms-creating the prospect that a requesting party might have to shoulder some of the expense of production where hard-to-recover electronically stored information is involved-represent a move in the restrictive direction discussed below. See Fed. R. Civ. P. 26(b)(2)(B) (permitting a court to set forth conditions for the discovery of electronically stored information from inaccessible sources).

28 United Mine Workers of Am. v. Gibbs, 383 U.S. 715, 724 (1966) ("Under the Rules, the 
rigidity of the common-law pleading system. ${ }^{29}$ The compulsory-counterclaim rule is an example of not only permitting the assertion of related claims within a single action but compelling it: "The requirement that counterclaims arising out of the same transaction or occurrence as the opposing party's claim 'shall' be stated in the pleadings was designed to prevent multiplicity of actions and to achieve resolution in a single lawsuit of all disputes arising out of common matters." 30 Of course, supplemental jurisdiction supports this liberal joinder system by allowing jurisdictionally insufficient claims to be heard in federal court on the basis of their relationship with other claims in the action. ${ }^{31}$ In sum, claim and party joinder have as their principal rationale the avoidance of multiple lawsuits pertaining to similar and closely related matters, something which in most instances promotes the private economic interests of litigants. ${ }^{32}$ We see, then, that the liberal ethos favors access to courts, resolution of disputes on their merits, and the inexpensive and timely prosecution and defense of claims.

\section{The Restrictive Ethos}

Although the values that comprise the liberal ethos-access, accuracy, and private efficiency-are familiar, they may seem quaint to the practitioner or serious student of civil procedure. Not that these values were not in view of the drafters of the Rules or do not reflect some part of their nature today; rather, it turns out that there are additional values that animate civil procedure, albeit in a contrary manner than those of the liberal ethos. These counter-values, if you will, form what I refer to as the restrictive ethos in civil procedure.

impulse is toward entertaining the broadest possible scope of action consistent with fairness to the parties; joinder of claims, parties and remedies is strongly encouraged." (footnote omitted)).

29 Blair v. Cleveland Twist Drill Co., 197 F.2d 842, 845 (7th Cir. 1952) ("Rules 13 and 14 are both intended to avoid circuity of action and to dispose of the entire subject matter arising from one set of facts in one action, thus administering complete and evenhanded justice expeditiously and economically."); see also Lasa per L'Industria del Marmo Societa per Azioni v. Alexander, 414 F.2d 143, 147 (6th Cir. 1969) ("The words 'transaction or occurrence' are given a broad and liberal interpretation in order to avoid a multiplicity of suits.").

30 S. Constr. Co. v. Pickard, 371 U.S. 57, 60 (1962) (per curiam). The quoted "shall" language of Rule 13(a) was replaced with the thought-to-be-more-modern "must" as part of the restyling amendments that took effect December 1, 2007.

31 See Michelle S. Simon, Defining the Limits of Supplemental Jurisdiction Under 28 U.S.C. § 1367: A Hearty Welcome to Permissive Counterclaims, 9 Lewis \& Clark L. Rev. 295, 298 (2005) ("[S]upplemental jurisdiction promotes fairness and judicial economy, and complements the liberal joinder rules of the Federal Rules of Civil Procedure.").

327 Charles Alan Wright, Arthur R. Miller \& Mary Kay Kane, Federal Practice ANd Procedure: Civil $§ 1652$ (3d ed. 2001). 
The major counter-value within the restrictive ethos is a threshold skepticism that yields an interest in excluding or discouraging claims rather than supporting and encouraging them. The open-access approach of the Federal Rules was not a welcome development in the eyes of all observers. ${ }^{33}$ Many jurists, particularly after the strengthening of the damages-class device under Rule $23^{34}$ and the stream of public-rights legislation in the 1960s, felt that too many meritless claims were flooding the courts: "Relatively low barriers to entry have ... generated an undesirable result-a deluge of frivolous or vexatious claims filed by the uninformed, the misinformed, and the unscrupulous." 35 The response was a so-called "counterrevolution" 36 that asserted that "the underlying ideology of liberality of pleading, wideopen discovery and attorney latitude was no longer feasible" 37 and sought to use procedural reforms to "keep out the worthless, the trivial, and those litigations which . . . ought not to be in the courts[.]"38 Specifically, as a solution to the litigation explosion and perceived abuses of discovery and the civil process in general, this group of reformers promulgated a series of rule changes and practices that sought to clamp down on frivolous filings.

33 See, e.g., Laurens Walker, The Other Federal Rules of Civil Procedure, 25 REv. Litig. 79, 85 (2006) ("Rule 8's near elimination of any meaningful requirement that plaintiffs initially apprise the court of a basis for relief provoked judicial hostility from the very beginning."). In 1952 the Ninth Circuit Judicial Conference voiced this hostility by adopting a resolution proposing that Rule 8(a)(2) be amended to read, "(2) a short and plain statement of the claim showing that the pleader is entitled to relief, which statement shall contain the facts constituting a cause of action." Claim or Cause of Action: A Discussion on the Need for Amendment of Rule 8(a)(2) of the Federal Rules of Civil Procedure, 13 F.R.D. 253, 253 (1953).

34 See Fed. R. Civ. P. 23(b)(3).

35 Lepucki v. Van Wormer, 765 F.2d 86, 87 (7th Cir. 1985) (per curiam); see also Selvy v. Dep't of Hous. \& Urban Dev., 371 F. Supp. 2d 905, 908 (E.D. Mich. 2005) ("[A]lthough open access to the Courts is essential, ... a at a certain point, a '[c]ourt's goal of fairly dispensing justice becomes compromised when [it] is forced to devote its limited resources to the processing of repetitious and frivolous requests." (quoting Zatko v. California, 502 US. 16, 17 (1991) (per curiam)); Carl Tobias, Civil Justice Reform and the Balkanization of Federal Civil Procedure, 24 ARIz. ST. L.J. 1393, 1396 (1992) ("These observers [including many judges and some writers] contended that lawyers and litigants were filing a substantial number of civil cases, too few of which had merit.").

36 D. Michael Risinger, Another Step in the Counter-Revolution: A Summary Judgment on the Supreme Court's New Approach to Summary Judgment, 54 Brook. L. Rev. 35, 35 (1988) ("[T]here seems to be an emerging consensus that federal civil procedure is in the midst of a counterrevolution ....").

37 Stephen N. Subrin, Teaching Civil Procedure While You Watch It Disintegrate, 59 Brook. L. Rev. 1155, 1158 (1993).

38 Simon H. Rifkind, Are We Asking Too Much of Our Courts?, in The Pound Conference: Perspectives on Justice in the Future 51, 61 (A. Leo Levin \& Russell R. Wheeler eds., 1979). 
In 1983, Rule 16 was amended to empower judges to manage litigation more actively during the pretrial phase and to pare off meritless claims as they saw fit. ${ }^{39}$ Many judges obliged, using pretrial case management techniques to expedite proceedings, impose sanctions for abusive conduct, and coax parties toward settlement. ${ }^{40}$ Rule 11 was amended that same year to make sanctions mandatory and to eliminate the "good-faith" standard for judging the prefiling inquiry that supports the allegations in a pleading. ${ }^{41}$ Changes in this and other aspects of the rule could chill some litigants from bringing meritorious claims. ${ }^{42}$ In fact, it is by now commonly felt that prior to the amendment to its current form in the early 1990s, Rule 11 was disproportionately used to sanction plaintiffs' counsel in civil rights actions. ${ }^{43}$

39 FED. R. CIV. P. 16(c)(2) ("[T]he court may consider and take appropriate action on the following matters: formulating and simplifying the issues, and eliminating frivolous claims or defenses ....").

40 Tobias, supra note 35, at 1396 ("Many judges participated more actively in expediting dispute resolution. They used pretrial conferences to set lawsuits' pace, to structure questions at issue, or to foster settlement, concomitantly experimenting with Alternative Dispute Resolution (ADR).").

41 See Fed. R. Civ. P. 11, 28 U.S.C. app. 575 (1988) (amended 2007); Fed. R. Civ. P. 11 advisory committee's notes to 1983 amendments ("The new language is intended to reduce the reluctance of courts to impose sanctions ...."). Rule 11 was amended in 2007 to put the imposition of sanctions within the discretion of the court once again. See FED. R. Civ. P. 11(c).

42 Cf. Yamamoto, supra note 8, at 397 ("A rule structured to deter all frivolous filings may be neutral by its terms and nevertheless partial in its effects. Certain types of potential litigants may be more severely impacted because their social situation generates disproportionate numbers of claims deemed frivolous by current norms.").

43 See Stephen B. Burbank, The Transformation of American Civil Procedure: The Example of Rule 11, 137 U. PA. L. REv. 1925, 1938 (1989) ("We also know that for the same one-year period [June 30, 1987, through July 1, 1988] in the Third Circuit, Rule 11 had a disproportionately adverse impact on civil rights plaintiffs, in that civil rights plaintiffs, their lawyers, or both were sanctioned at a rate $(47.1 \%)$ far higher than the rate for plaintiffs as a whole $(15.9 \%)$, and higher still than the rate for plaintiffs in non-civil rights cases $(8.45 \%)$."); see also Danielle Kie Hart, Still Chilling After All These Years: Rule 11 of the Federal Rules of Civil Procedure and Its Impact on Federal Civil Rights Plaintiffs Afier the 1993 Amendments, 37 VAL. U. L. ReV. 1, 12-13 (2002) ("Several informal and formal studies of Rule 11 were conducted. The early studies found that plaintiffs were sanctioned much more frequently than defendants, particularly in civil rights cases." (footnote omitted)). But see id. at 13-15 ("More recent studies provide somewhat conflicting information. ... In one study, conducted by the Federal Judicial Center in 1990 (the "FJC study"), federal district court judges were questioned. In another study, conducted by the American Judicature Society and published in 1992 (the "AJS study"), attorneys practicing in three federal circuits were surveyed. . . . [T] he FJC study, which focused on federal district court judges' reactions to Rule 11, concluded that sanctions were sought more often against plaintiffs than defendants and that motions for sanctions against plaintiffs were more likely to be granted than those against defendants. The FJC study also concluded, however, that civil rights plaintiffs were not disproportionately impacted by Rule 11. Like the FJC study, the AJS study also found that plaintiffs and their counsel were the target of Rule 11 sanction activity to a far greater extent than defendants and their counsel. Unlike the FJC study, however, the AJS study 
The history of the imposition of heightened pleading standards to frustrate the prosecution of certain types of cases, most notably antitrust and civil rights claims, ${ }^{44}$ has also been well documented. ${ }^{45} \mathrm{Al}$ though the Supreme Court had steadfastly rejected this practice, ${ }^{46}$ more recently - as a result of its decisions in Bell Atlantic Corp. v. Twombly ${ }^{47}$ and Ashcroft v. Iqbal ${ }^{48}$ - the Court has signaled that its commitment to notice pleading has waned. ${ }^{49}$ Congress has even got-

concluded that civil rights cases were disproportionately impacted by Rule 11." (footnotes omitted)).

44 Professor Roy Brooks has commented as follows on the phenomenon of heightened pleading in the civil-rights context:

From a [Critical Race Theory] perspective, application of any heightened pleading standard to civil rights cases constitutes racial subordination. The heightened pleading standard disadvantages the civil rights plaintiff by imposing the difficult, if not impossible, burden of making specific factual allegations about events known only to the defendant. The defendant is not required to disclose this information to the plaintiff until discovery, yet the plaintiff is forced to plead such unknown facts to prevent the dismissal of her civil rights claim. The heightened pleading standard, therefore, means that civil rights plaintiffs are required to plead facts that non-civil rights plaintiffs are not expected to know prior to discovery.

Roy L. Brooks, Critical Race Theory: A Proposed Structure and Application to Federal Pleading, 11 Harv. BlackLetter L.J. 85, 107 (1994) (footnote omitted).

45 See Christopher M. Fairman, The Myth of Notice Pleading, 45 ArIz. L. REv. 987, 988 (2003); see also Phyllis Tropper Baumann, Judith Olans Brown \& Stephen N. Subrin, Substance in the Shadow of Procedure: The Integration of Substantive and Procedural Law in Title VII Cases, 33 B.C. L. Rev. 211, 243-52 (1992).

46 See Swierkiewicz v. Sorema N.A., 534 U.S. 506, 512 (2002) ("[I]mposing the Court of Appeals' heightened pleading standard in employment discrimination cases conflicts with Federal Rule of Civil Procedure 8(a)(2), which provides that a complaint must include only 'a short and plain statement of the claim showing that the pleader is entitled to relief." "); Leatherman $\mathbf{v}$. Tarrant County Narcotics Intelligence \& Coordination Unit, 507 U.S. 163, 168 (1993) ("We think that it is impossible to square the 'heightened pleading standard' applied by the Fifth Circuit in this case with the liberal system of 'notice pleading' set up by the Federal Rules."); Conley v. Gibson, 355 U.S. 41, 47 (1957) ("[T]he Federal Rules of Civil Procedure do not require a claimant to set out in detail the facts upon which he bases his claim."); see also Pratt v. Tarr, 464 F.3d 730 (7th Cir. 2006) (rejecting heightened pleading standard in prisoner civil-rights case based in part on the foregoing Supreme Court cases). But see Dura Pharm. Inc. v. Broudo, 544 U.S. 336, 347 (2005) ("We concede that ordinary pleading rules are not meant to impose a great burden upon a plaintiff. But it should not prove burdensome for a plaintiff who has suffered an economic loss to provide a defendant with some indication of the loss and the causal connection that the plaintiff has in mind." (citation omitted)).

47 Bell Atl. Corp. v. Twombly, 127 S. Ct. 1955 (2007).

48 Ashcroft v. Iqbal, 129 S. Ct. 1937 (2009).

49 Id. at 1950 (articulating a need, at the pleading stage, for factual allegations that "plausibly" suggest entitlement to relief). Opinions differ on the import of Twombly, although there seems to be some support for the notion that it has had a predictably adverse impact on prospective civil rights claims. See A. Benjamin Spencer, Pleading Civil Rights Claims in the Post-Conley Era, 52 How. L.J. 99, passim (2008) [hereinafter Spencer, Pleading Civil Rights Claims] (discussing post-Twombly treatment of civil rights complaints); see also Kendall W. Hannon, 
ten involved; in passing the Private Securities Litigation Reform Act of 1995, 50 it imposed heightened pleading standards on claimants asserting securities-fraud claims. ${ }^{51}$ Beyond stricter pleading standards, plaintiffs still face difficulty in having amendments to those pleadings relate back when they seek to change unknown defendants to identified defendants, ${ }^{52}$ a rule that seems to impact victims of alleged lawenforcement misconduct the most. ${ }^{53}$ Those claimants making it to the summary judgment stage face significant hurdles as well, particularly in light of the ease with which defendants may raise such challenges in the wake of the Celotex trilogy of cases. ${ }^{54}$ Indeed, if the amendments

Much Ado About Twombly? A Study on the Impact of Bell Atlantic Corp. v. Twombly on 12(b)(6) Motions, 83 Notre Dame L. Rev. 1811, 1815 (2008) ("[T]he one area in which this study does show a significant departure from previous dismissal practice is the civil rights field." (emphasis omitted)). Professor Bone, however, argues that the change wrought by Twombly is not as dramatic as others, including myself, have suggested. Robert G. Bone, Twombly, Pleading Rules, and the Regulation of Court Access, 94 Iowa L. Rev. 873, 878 (2009) ("Twombly's pleading standard neither signals a return to code fact pleading nor represents a sharp break from the vision of the 1938 Federal Rule drafters, as some critics have argued."). I propound the view that Twombly works a major change in pleading doctrine in Plausibility Pleading, supra note 3, at 49, and touch on Professor Bone's views in Understanding Pleading Doctrine, $108 \mathrm{MiCH}$. L. Rev. 1,24 (2009).

50 Private Securities Litigation Reform Act of 1995, Pub. L. No. 104-67, 109 Stat. 737 (codified at 18 U.S.C. $\$ 1964$ and in scattered sections of 15 U.S.C.).

51 See 15 U.S.C. § 78u-4(b)(1)-(2) (2006); Leslie M. Kelleher, Taking "Substantive Rights" (in the Rules Enabling Act) More Seriously, 74 Notre Dame L. Rev. 47, 60 (1998) ("The strict pleading requirement of the [Private Securities Litigation Reform Act] . . . is designed to favor defendants over plaintiffs in securities lawsuits, not to implement some carefully planned vision of the procedural system.").

52 See, e.g., Bell v. City of Topeka, 279 F. App’x 689, 692 (10th Cir. 2008) (“[A] plaintiff's designation of an unknown defendant . . . in the original complaint is not a formal defect of the type [Rule 15(c)(1)(C)] was meant to address, and a later amendment that specifically names that defendant does not relate back to the original complaint." (internal quotation marks and citation omitted)); see also Moore v. Tennessee, 267 F. App'x 450, 455 (6th Cir. 2008) ("In this court, a plaintiff's lack of knowledge pertaining to an intended defendant's identity does not constitute a 'mistake concerning the party's identity' within the meaning of Rule 15(c)."). The Moore court cited cases from seven other circuit courts that were in accord with its judgment. See id.

53 Many may recall how this interpretation of the relation-back rule prevented an alleged victim of police brutality from bringing suit against named police officers in Worthington $v$. Wilson, 790 F. Supp. 829, 834-35 (C.D. Ill. 1992), affd, 8 F.3d 1253 (7th Cir. 1993).

54 In Celotex Corp. v. Catrett, 477 U.S. 317 (1986), the Supreme Court held that there is no requirement that a "moving party support its motion [for summary judgment] with affidavits or other similar materials negating the opponent's claim." Id. at 323. In Anderson v. Liberty Lobby, Inc., 477 U.S. 242 (1986), the Court held that the substantive evidentiary standard of proof applicable at trial applies to the summary judgment decision. Id. at 252. The third case in the trilogy, Matsushita Electric Industrial Co. v. Zenith Radio Corp., 475 U.S. 574 (1986), stated that "if the factual context renders respondents' claim implausible-if the claim is one that simply makes no economic sense-respondents must come forward with more persuasive evidence to support their claim than would otherwise be necessary." Id. at 587. Although these decisions 
to Rule 56 currently under consideration ${ }^{55}$ take effect in their current form, plaintiffs may face even more difficulty and expense in resisting the termination of their case on summary judgment. ${ }^{56}$

On the class-action front, plaintiffs have faced challenging classcertification standards for classes seeking primarily money damages. For example, Rule 23(b)(3) requires that common questions of law or fact predominate over questions affecting only individual class members $^{57}$ and multistate classes requiring the application of disparate state legal rules typically will not pass that test. ${ }^{58}$ Further, the costs of proceeding as a class seeking money damages may at times be prohibitive given the plaintiffs' obligation to pay for notice to class members. $^{59}$ That federal class-certification standards are stringent ${ }^{60}$ has been recognized by Congress, which cited those strict standards as a primary rationale for moving more putative classes from state into

would tend to make summary judgment motions easier to assert and more daunting for plaintiffs, a study by the Federal Judicial Center claims that there is not much evidence supporting the idea that the Celotex trilogy led to an increase in such motions. See Joe S. Cecil et al., A QuarterCentury of Summary Judgment Practice in Six Federal District Courts, 4 J. EMPIRICAL Legal STud. 861, 906 (2007).

55 See Advisory Comm. on Fed. Rules of Civil Procedure, Judicial Conference of U.S., Report on Proposed Amendments to Rules 26 and 56 of the Federal Rules of Civil Procedure 21-56 (2008), available at http://www.uscourts.gov/rules/Reports/ CV_Report.pdf. The proposed amendments include a revision to the process surrounding Rule 56 motions, referred to as a "point-counterpoint procedure." Id. at 24.

56 See Letter from Stephen B. Burbank, Professor of Law, Univ. of Pa. Law School, to Peter G. McCabe, Sec'y, Comm. on Rules of Practice \& Procedure, Admin. Office of the U.S. Courts, at 2, 6-8 (Jan. 28, 2009), available at http://www.uscourts.gov/rules/2008\%20Comments \%20Committee\%20Folders/CV\%20Comments\%202008/08-CV-145-Comment-Burbank.pdf (pointing out the potential problems of cost, delay, frustration of the jury right, and strategic gamesmanship that could flow from imposition of the point-counterpoint procedure proposed in amended Rule 56).

57 See, e.g., Unger v. Amedisys Inc., 401 F.3d 316, 320 (5th Cir. 2005) ("The predominance element requires a finding that common issues of law or fact 'predominate over any questions affecting only individual members.' [Rule 23(b)(3).] This requirement, although reminiscent of the commonality requirement of Rule 23(a), is 'far more demanding' because it 'tests whether proposed classes are sufficiently cohesive to warrant adjudication by representation.'" (quoting Amchem Prods., Inc. v. Windsor, 521 U.S. 591, 623-24 (1997))).

58 See, e.g., In re Vioxx Prod. Liab. Litig., 239 F.R.D. 450, 460-62 (E.D. La. 2006).

59 See Eisen v. Carlisle \& Jacquelin, 417 U.S. 156, 178-79 (1974) (holding that "[w]here ... the relationship between the parties is truly adversary, the plaintiff must pay for the cost of notice as part of the ordinary burden of financing his own suit").

60 See, e.g., In re Hydrogen Peroxide Antitrust Litig., 552 F.3d 305, 320 (3d Cir. 2008) ("Class certification requires a finding that each of the requirements of Rule 23 has been met. Factual determinations necessary to make Rule 23 findings must be made by a preponderance of the evidence. In other words, to certify a class the district court must find that the evidence more likely than not establishes each fact necessary to meet the requirements of Rule 23." (footnote and citations omitted)). 
federal court through the Class Action Fairness Act ${ }^{61}$ passed in $2005 .{ }^{62}$ Ultimately, a restrictive interpretation of class-certification standards tends to preclude classes from proceeding to a resolution of their claims on the merits. ${ }^{63}$

Certainly, efforts to constrain discovery, most notably through amending Rule 26 to limit the scope of discovery to material related to claims or defenses in the action rather than the subject matter of the action, reflect a desire to discourage "fishing expeditions" that might yield additional claims and to protect litigants-mainly defendants-against the high costs associated with complex discovery. These efforts were spurred in part by longstanding concerns about "predatory discovery" 64 or "discovery abuse"65 - the perception that plaintiffs were using their ability to impose discovery costs on their opponents as a means of coercing them into early settlements. ${ }^{66} \mathrm{Al}-$ though the Supreme Court at one time seemed to endorse the idea

61 Class Action Fairness Act of 2005, Pub. L. No. 109-2, 119 Stat. 4 (codified as amended in scattered sections of 28 U.S.C.).

62 See S. REP. No. 109-14, at 6 (2005), reprinted in 2005 U.S.C.C.A.N. 3,7 ("This Committee believes that the current diversity and removal standards as applied in interstate class actions have facilitated a parade of abuses ...."); id. at 14, 2005 U.S.C.C.A.N. at 14 ("[S]ome state court judges are less careful than their federal court counterparts about applying the procedural requirements that govern class actions."); see also A. Benjamin Spencer, Anti-Federalist Procedure, 64 W ASH. \& LeE L. Rev. 233, 246 (2007) (criticizing Congress for, through the Class Action Fairness Act, "indulging its anti-federalist impulses to impose on the judicial authority of states based on its dissatisfaction with the results that state courts were producing when they adjudicated state law claims over which they properly had jurisdiction").

63 See Stephen C. Yeazell, The Misunderstood Consequences of Modern Civil Process, 1994 WIs. L. Rev. 631, 655 (1994) ("In a class action involving a large group whose members claim only a small harm was inflicted on each of them, virtually the only important judicial ruling is whether to certify the class under Rule 23 , a decision that occurs without even a glance at the merits.").

64 Marrese v. Am. Acad. of Orthopaedic Surgeons, 726 F.2d 1150, 1162 (7th Cir. 1984) (en banc), rev'd, 470 U.S. 373 (1985).

65 Section of Lrtig., Am. Bar Ass'n, Report of the Special Committee for the Study OF Discovery Abuse 1 (1977).

66 See William H. Erickson, The Pound Conference Recommendations: A Blueprint for the Justice System in the Twenty-Fïst Century, 76 F.R.D. 277, 288 (1978) ("Unnecessary intrusions into the privacy of the individual, high costs to the litigants, and correspondingly unfair use of the discovery process as a lever toward settlement have come to be part of some lawyers' trial strategy."); see also ACF Indus., Inc. v. EEOC, 439 U.S. 1081, 1086-87 (1979) (Powell, J., dissenting from denial of certiorari) ("[T]he widespread abuse of discovery . . is a prime cause of delay and expense in civil litigation. . . . [U]ntil rule changes can be made, there is a pressing need for judicial supervision in this area."); Marrese, 726 F.2d at 1161 ("[W]e may not ignore as judges what we know as lawyers-that discovery of sensitive documents is sometimes sought not to gather evidence that will help the party seeking discovery to prevail on the merits of his case but to coerce his opponent to settle regardless of the merits rather than have to produce the documents."). 
that "fishing expeditions" were allowed under the discovery rules, ${ }^{67}$ lower courts ${ }^{68}$ and even the Supreme Court itself ${ }^{69}$ seem to have settled on the contrary view. The new electronic-discovery rules, which permit producing parties to withhold information that is not reasonably accessible and allow the sharing of costs associated with burdensome production, ${ }^{70}$ reflect a prioritization of cost control over the interests of accurate resolution of disputes. ${ }^{71}$

Finally, the restrictive ethos finds a voice in jurisdictional rules and doctrines. Personal jurisdiction doctrine seems tilted against plaintiffs given its excessive concern with convenience to defendants ${ }^{72}$ and tendency to preclude plaintiffs from bringing cases against out-ofstate defendants in the plaintiffs' home state where they may have been harmed, particularly in the Internet context. ${ }^{73}$ Aspects of federal subject-matter jurisdiction are access-restrictive as well. Although diversity jurisdiction in some ways has expanded (such as, in a backhanded way, via the Class Action Fairness Act $^{74}$ or the corporate-

67 Hickman v. Taylor, 329 U.S. 495, 507 (1947) ("[T]he deposition-discovery rules are to be accorded a broad and liberal treatment. No longer can the time-honored cry of 'fishing expedition' serve to preclude a party from inquiring into the facts underlying his opponent's case.").

68 E.g., Bruno \& Stillman, Inc. v. Globe Newspaper Co., 633 F.2d 583, 597 (1st Cir. 1980) ("As a threshold matter, the court should be satisfied that a claim is not frivolous, a pretense for using discovery powers in a fishing expedition. In this case, plaintiff should show that it can establish jury issues on the essential elements of its case not the subject of the contested discovery.").

69 See Bell Atl. Corp. v. Twombly, 127 S. Ct. 1955, 1967 (2007) ("[P]roceeding to antitrust discovery can be expensive. ... '[A] district court must retain the power to insist upon some specificity in pleading before allowing a potentially massive factual controversy to proceed.'” (quoting Associated Gen. Contractors of Cal., Inc. v. Carpenters, 459 U.S. 519, 528 n.17 (1983))).

70 Fed. R. Civ. P. 26(b)(2)(B).

71 Although the cost concerns associated with the production of inaccessible electronically stored information are valid, the question is whether a rule that presumptively protects such information against production will have an unfair adverse impact on litigants' access to the information they need to make their case.

72 See A. Benjamin Spencer, Jurisdiction to Adjudicate: A Revised Analysis, 73 U. CHI. L. REv. 617, 618 (2006) (describing personal jurisdiction doctrine as "a confused defendant-centric doctrine obsessed with defendants' intentions, expectations, and experiences of inconvenience").

73 See, e.g., Young v. New Haven Advocate, 315 F.3d 256, 258-59 (4th Cir. 2002) (rejecting effort of plaintiff to assert personal jurisdiction over out-of-state newspaper allegedly placing defamatory content on its universally available website because the Connecticut newspaper did not "aim [its] website or the posted articles at a Virginia audience"). Compare the prevailing American approach to Internet jurisdiction-which favors defendants-with the approach in Australia, which permits a clearly more claimant-oriented approach to personal jurisdiction. See, e.g., Dow Jones \& Co. v. Gutnick (2002) 210 C.L.R. 575, 606-07 (stating that victims of defamation may bring claims in the jurisdiction "at the place where the damage to reputation occurs" and that in the Internet context the damage to reputation is done where the claimant downloads the injurious material).

74 See supra notes $61--62$ and accompanying text. 
citizenship rule ${ }^{75}$ ), the amount-in-controversy requirement continues to be increased periodically to exclude smaller claims from federal court. Additionally, the doors of the federal courts are closed completely to those seeking a federal forum for the enforcement of childor spousal-support obligations even though such disputes otherwise might qualify for diversity jurisdiction. ${ }^{76}$ It is also worth noting that appellate-court jurisdiction was recently restricted by treating a statutory time limit for appeal as jurisdictional, preventing a plaintiff who had relied on a district-court extension beyond the time limit from having his appeal heard. ${ }^{77}$

In sum, from this cursory survey of contemporary civil procedure and its major pressure points we can see that a collection of procedural rules and reforms reflect a restrictive ethos, characterized by a desire to discourage certain claims and to keep systemic litigation costs under control.

\section{Resolving the Tension: A Dialectical Analysis}

As we have seen, there are two sides to civil procedure. The first is access-promoting and favors resolution of disputes on the merits. The other is more restrictive and cost-conscious, creating various doctrines that frustrate the assertion and prosecution of potentially meritorious claims. In other words, much of procedure is expressly directed not at the traditional goal of facilitating accurate outcomes, but rather is designed and applied to frustrate or at least subordinate accuracy in certain contexts where efficiency of some sort or the interests of certain litigants are at stake.

75 The corporate-citizenship rule holds that a corporation is only a citizen of its state of incorporation and the state where it has its principal place of business for purposes of diversity jurisdiction. 28 U.S.C. § 1332(c)(1) (2006); see also Louisville, Cincinnati, \& Charleston R.R. v. Letson, 43 U.S. (2 How.) 497 (1844) (holding that a corporation's citizenship is determined independently of the citizenship of its owners). This rule enabled corporations to gain greater access to the thought-to-be-more-hospitable federal courts. The rule correspondingly limited the ability of the adversaries of corporations to proceed against them in state courts.

76 Ankenbrandt v. Richards, 504 U.S. 689, 695, 703 (1992) (noting that "the Constitution does not exclude domestic relations cases from the jurisdiction otherwise granted by statute to the federal courts" but indicating that such cases are excluded based on an interpretation of the federal diversity statute). For criticism of the domestic-relations exception, see generally Jill Elaine Hasday, Federalism and the Family Reconstructed, 45 UCLA L. Rev. 1297 (1998); Judith Resnik, "Naturally" Without Gender: Women, Jurisdiction, and the Federal Courts, 66 N.Y.U. L. REv. 1682 (1991).

77 Bowles v. Russell, 127 S. Ct. 2360, 2366 (2007) ("Bowles' failure to file his notice of appeal in accordance with the statute therefore deprived the Court of Appeals of jurisdiction. And because Bowles' error is one of jurisdictional magnitude, he cannot rely on forfeiture or waiver to excuse his lack of compliance with the statute's time limitations."). 
These two sides of procedure coexist, although their opposing tendencies create a tension that cries for resolution. Resolution of this tension may be found in realizing that the liberal ethos and the restrictive ethos are dialectically related. That is, the basic thesis of procedure, its liberal ethos, yields its antithesis, the restrictive ethos, and the two can be reconciled through a synthesis that helps us understand how these seemingly contradictory attitudes cooperate toward a unified, more fundamental goal.

Professor Subrin has already demonstrated how the liberal aspects of civil procedure-which are primarily rooted in historical equity practices-resulted in a system that so favored access that certain observers felt the need to introduce the array of access-restricting reforms discussed above. ${ }^{78}$ That is, the pursuit and realization of the liberal ethos is the very thing that generates its antithesis, the restrictive ethos; the goals promoted by the liberal ethos generate a systemic need for counter-values that can address the challenging or burdensome products of the liberal procedural ideal. Greater access to courts naturally increases the volume of litigation the system must handle and presents a greater opportunity to put forth claims asserting seemingly tenuous or disfavored rights. Seeking the resolution of disputes on their merits requires permitting parties a degree of freedom in asserting and establishing their claims that can subject adversaries and the courts to lengthy and expensive processes and proceedings. The costs and burdens seemingly imposed on courts and defending parties by the liberal ethos gives rise to a collection of counter-values that seek to suppress the volume of claims and facilitate courts' ability to manage and dispose of claims sooner and more efficiently than a truly merits-centered system might allow. ${ }^{79}$ In sum, access, simplicity, and affordability generate an overwhelming volume of (to some, un-

78 See Stephen N. Subrin, How Equity Conquered Common Law: The Federal Rules of Civil Procedure in Historical Perspective, 135 U. PA. L. REv. 909, 982 (1987) (noting that "recent trends to amend the Federal Rules as well as the developments in alternative dispute resolution have emerged, at least in considerable part, in response to the chaos" caused by the equitable nature of the rules, which "permitted the participation of virtually unlimited numbers of people in trials and the consideration of a similar array of theories and facts").

79 See, e.g., Stempel, supra note 13, at 537-38 ("Arguably, the very success of these efforts to effect the 1938 Rules were what created the counterrevolution of the late Twentieth Century's discovery reform movements."). 
desirable) litigation activity ${ }^{80}$ that restrictive values are designed to suppress. ${ }^{81}$

So on one level, the synthesis of the liberal ethos and the restrictive ethos might be in the nature of a checks-and-balances relationship: the restrictive ethos checks the excesses of the liberal ethos and vice versa. I believe, however, there is more to it than that. Although the checks-and-balances concept might accurately describe the relationship between the liberal and restrictive aspects of civil procedure in some respects, in reality it seems that the liberal ethos is in many respects overshadowed by the restrictive. ${ }^{82}$ That is, although one can identify those liberal aspects of procedure in contemporary rules and doctrines, the restrictive ethos in procedure appears ascendant and poised for dominance. The Supreme Court's capitulation to defendant requests for more stringent pleading standards in Bell Altantic Corp. v. Twombly and Ashcroft v. Iqbal is the clearest evidence of procedure's tilt towards restrictiveness. In Twombly, the Court was unashamed to cite discovery abuse as a ground for preventing plaintiffs from proceeding to discovery on the basis of equivocal pleading that might have satisfied Conley v. Gibson's "no set of facts" standard. ${ }^{83}$ In light of the zeal with which lower courts have embraced a restrictive interpretation of Twombly, ${ }^{84}$ and the Court's reinforcement of restrictive pleading standards in Iqbal, ${ }^{85}$ many litigants now face a potentially substantial obstacle to accessing the system to assert their claims. The Class Action Fairness Act, the narrow view of personal

80 Deborah R. Hensler et al., Rand Inst. for Civil Justice, Class Action Dilemmas: Pursuing Public Goals for Private Gain 49 (2000) ("[A]ny change in court processes that provides more efficient means of litigating is likely to enable more litigation. Greater efficiency can lower the costs of bringing lawsuits, making it more attractive for litigants to sue and for lawyers to take their cases."); Subrin, supra note 78, at 912, 944 (arguing that the prevalence of equity procedure within the Federal Rules "represents a major contributing factor to many of the most pressing problems in contemporary civil procedure" and that "courts continue to live with the chaotic results of this uncontrolled and uncontrolling procedural system").

81 Professor Yamamoto described the obstructionist perspective on the suppression of undesirable litigation well when he wrote, "From a utilitarian perspective, some indignity suffered by a minority of the populace [denied access to the courts] is an unavoidable and tolerable result of system shrinkage in the interest of ef ficiency." Yamamoto, supra note 8, at 390.

82 This observation echoes that of Professor Walker, who recently opined that various common-law procedural doctrines, the so-called "Other Rules" of civil procedure, "interact with the 1938 Rules in such a way as to counter the apparent progressive character of the 1938 Rules and produce a functioning system which is not progressive in reality but conservative." Walker, supra note 33 , at $80-81$ (footnote omitted).

83 Bell Atl. Corp. v. Twombly, 127 S. Ct. 1955, 1967-69 (2007).

84 See Spencer, Pleading Civil Rights Claims, supra note 49, at 141-55.

85 Ashcroft v. Iqbal, 129 S. Ct. 1937, 1950 (2009) ("[O]nly a complaint that states a plausible claim for relief survives a motion to dismiss." (citing Twombly, 127 S. Ct. at 1965)). 
jurisdiction in the Internet context, the discovery-scope amendment, and limitations on the discovery of burdensome electronically stored information all additionally evince the dominance of restrictiveness, and together reflect the culmination of a move toward restrictiveness begun with the counter-revolutionary changes to Rule 16, Rule 11, and summary judgment that appeared only a generation ago. ${ }^{86}$

Given the simultaneous presence of a dominant restrictive ethos and the visible vestiges of the liberal ethos within civil procedure, I would describe the synthesis of the two not merely as a checks-andbalances relationship. Rather, the restrictive ethos enables the civil justice system to survive by reducing the number of disfavored actions that burden the system while the more popularly known liberal ethos takes on the role of generating and sustaining the legitimacy of, and faith in, the civil justice system in the eyes of the public at large. In other words, procedure's central thesis (the liberal ethos) and antithesis (the restrictive ethos) can be synthesized into a concept I refer to as ordered dominance: procedure's overarching, unified goal is to facilitate and validate the substantive outcomes desired by society's dominant interests; procedure's veneer of fairness and neutrality maintains support for the system while its restrictive doctrines weed out disfavored actions asserted by members of social out-groups and ensure desired results. ${ }^{87}$

By "dominant interests" I mean the commercial class that uses the courts to litigate traditional claims such as contract or property

86 Of course, restrictive impulses within the Federal Rules did not originate entirely within the past thirty years. The drafters were aware of the breadth of the system that they were creating and included measures such as the summary judgment device as one way to hold the line against the tenuous claims that their liberal pleading rules might allow. See Stephen B. Burbank, Vanishing Trials and Summary Judgment in Federal Civil Cases: Drifting Toward Bethlehem or Gomorrah?, 1 J. EmpiRICAL Legal STud. 591, 603 (2004) ("Rule 56 was intended to function as an equilibrating device that would discipline the results of notice pleading and profit from those of broad discovery."). By emphasizing the more recent developments in the direction of restrictiveness, I simply mean to suggest that explicit commitment to the restrictive ethos appears to have, over time, intensified, gained strength, and come to dominate those provisions that would otherwise be access-promoting in the Federal Rules.

87 As I explain below, I do not define the conflict between dominant interests and social out-groups in purely racialized, black-white terms, although others have done so. See, e.g., Brooks, supra note 44, at 111 ("Society and its institutions, including its legal system, express a white world-view, a perspective that necessarily operates to the benefit of whites at the expense of people of color. The federal courts' treatment of civil rights claims, including Rule 11 sanctions, is merely further evidence of this built-in bias." (footnote omitted)). Racial minorities asserting certain claims certainly fit within the out-group category but other groups, not defined simply by race (e.g., women, gays, the elderly, consumers, small investors), fall within this category as well. 
disputes, or who encounter the courts as civil defendants in all kinds of disputes. This group is important to the national economy and has the means and clout to influence policymakers at all levels of government. Civil procedure tends to favor the interests of these groups by keeping restrictive procedural doctrines (such as heightened pleading) from interfering with the resolution of ordinary commercial disputes ${ }^{88}$ and by protecting commercial defendants against claims by members of various out-groups.

By "out-groups" I mean "those outside the political and cultural mainstream, particularly those challenging accepted legal principles and social norms. ... [T] hose raising difficult and often tenuous claims that demand the reordering of established political, economic and social arrangements, that is, those at the system's and society's margins." 89 Dominant interests retain control over the mechanisms that control civil procedure, namely the federal judiciary and derivatively the membership of the federal rulemaking committees. ${ }^{90}$ In turn, those controlling the development of procedure since the 1970s have tended to prefer anti-access reforms that stymie the efforts of social out-groups to use the federal courts to vindicate their interests. ${ }^{91}$ These anti-access reforms-particularly stricter pleading and looser summary judgment standards-favor pretrial dispositions that ultimately keep resolution of these claims out of the hands of representative juries and firmly within the control of judicial elites.

88 Yamamoto, supra note 8, at 345 ("[The] procedural system [is] hospitable to litigants with disputes involving well-settled legal principles.").

89 Id. (footnote omitted).

90 It is worth noting that since the appointment of Chief Justice Warren Burger in 1969, the Chief Justices-and thus the persons in control of the membership of the various rulemaking committees-have been appointed by Republican presidents, who have tended to support litigation-reform efforts more than the interests of pro-plaintiff trial attorneys and consumer groups. See, e.g., Edward A. Purcell, Jr., The Class Action Fairness Act in Perspective: The Old and the New in Federal Jurisdictional Reform, 156 U. PA. L. REv. 1823, 1899 (2008) ("During Reagan's presidency, Republicans introduced 'tort reform' bills in Congress with increasing frequency ...."); Stephen Labaton, Bush Calls for Change in Handling Asbestos Lawsuits, N.Y. Times, Jan. 8, 2005, at A12. Professor Burbank points out that the civil-rules committee is dominated by judges rather than members of the bar, an imbalance that might put too heavy a thumb on the scale in favor of institutional interests that may favor only certain kinds of procedural reform. See Stephen B. Burbank, Procedure, Politics and Power: The Role of Congress, 79 Notre Dame L. Rev. 1677, 1714-15 (2004) ("Under Chief Justice Warren Burger, however, the Civil Rules Advisory Committee came to be heavily dominated by judges selected by the Chief Justice. This imbalance has continued ....").

91 Yamamoto, supra note 8, at 345 ("Reforms that discourage court access for minorities asserting 'marginal' rights claims reflect value judgments about the purposes of adjudication and the desirability of broad-based participation in the litigation process."). 
The idea of "disfavored actions" is already familiar. Allegations of fraud have been treated as disfavored for various reasons and thus the Federal Rules have always required that such claims be pleaded with particularity. ${ }^{92}$ Other actions have been "disfavored" as well; malicious prosecution, civil rights claims, securities claims, and antitrust claims have been treated by various courts throughout the history of the Federal Rules as disfavored and thus warranting a heightened pleading standard. ${ }^{93}$ Such claims have been singled out for disproportionate scrutiny under Rule 11 as well. ${ }^{94}$ Employment discrimination claims also seem to be disfavored given that summary judgment motions by defendants in such cases are relatively more likely to succeed. ${ }^{95}$

The idea of ordered dominance that I have described is certainly an oversimplification and likely fails to describe the whole of civil procedure accurately. However, it cannot be gainsaid that procedure today is recognized by all the relevant players-the rulemakers, the judiciary, members of Congress, interested lobbyists-as being vitally connected with substantive policy interests and that some of those same players have consciously tinkered with (or manipulated) procedural rules or doctrines with a clear understanding of their likely impact on certain substantive policy ends. ${ }^{96}$ Given that fact, it does not take much more investigation to reach the ordered-dominance thesis; none of the aforementioned players represent members of societal out-groups but rather are drawn from or represent privileged elites. ${ }^{97}$

92 Fed. R. Civ. P. 9(b); 5A Charles Alan Wright \& Arthur R. Miller, Federal Practice \& Procedure: Civil § 1296 (3d ed. 2004) (discussing, inter alia, the considerations that lead to the adoption of heightened pleading standards).

93 See Marcus, supra note 2, at 471-72.

94 Georgene M. Vairo, Rule 11: A Critical Analysis, 118 F.R.D. 189, 200 (1988) ("Rule 11 is being used disproportionately against plaintiffs, particularly in certain types of litigation such as civil rights [cases], employment discrimination [cases], securities fraud cases brought by investors, and antitrust cases brought by small companies.").

95 See Kevin M. Clermont \& Stewart J. Schwab, Employment Discrimination Plaintiffs in Federal Court: From Bad to Worse?, 3 HaRv. L. \& Pol'y Rev. 103, 128 (2009) (“[P]retrial adjudication particularly disfavors employment discrimination plaintiffs."); $c f$. Cecil et al., supra note 54 , at $886-89$ (noting the rise of summary judgment grants to defendants in civil rights cases, which presumably include employment discrimination claims).

96 See Burbank, supra note 90, at 1703-06 (describing Congress's increasing involvement in tinkering with civil procedure as it came to understand procedure's impact on its substantive policy goals); Richard L. Marcus, Of Babies and Bathwater: The Prospects for Procedural Progress, 59 BROOK. L. Rev. 761, 771-76 (1993) (discussing politicization of procedure and the "hidden agendas" of some rule reformers who seek to further their own substantive interests through civil-litigation reform).

97 For example, a cursory look at the membership of the current Advisory Committee on Civil Rules, which is available at http://www.uscourts.gov/rules/Members_List_07_2009.pdf, 
Although some among this group may fight for the interests of the out-groups when waging procedural battles, the restrictive regulatory and doctrinal outputs of procedural reform do not reveal much evidence in support of such a notion. To the contrary, modern procedural reforms, either through rulemaking, congressional intervention, or judicial interpretation, have bent towards the restrictive ethos, which undeniably has favored society's dominant interests as defined above.

\section{Conclusion}

Many may chafe at the idea of ordered dominance, given its seeming inconsistency with our traditional rhetoric of fair play, due process, and a day in court. Indeed, members of societal out-groups who are disadvantaged by the contemporary procedural regime may find the suggestion that civil procedure's restrictive ethos dominates its advertised liberal components particularly disheartening. But despondency is not the proper response to developing an understanding of the regime of ordered dominance revealed above. To the contrary, enlightenment is empowering; with a clear view of procedure one can articulate and advocate for appropriate reforms or, more likely, resist those reforms that are likely to further entrench the regime of ordered dominance.

Beyond enlightenment and empowerment, there is additional cause for hope. The concepts of access, fairness, and accuracy are powerful and deeply held ideals that likely enjoy universal public support. As long as these ideals remain part of the overall procedural scheme-whether as mere rhetoric or as actual working principlesthere is a base from which more progressive reformers can argue that beneath the rhetoric of litigation abuses and explosions lay individual litigants with grievances that have a right to be heard. The American commitment to justice and fairness can form a wellspring of devotion to the ideal that those who have been wronged should have access to a system that will right those wrongs and the belief that substantive rights should not be smoldered simply by the conniving of procedure. The challenge is to translate these popular notions into procedural realities, particularly in the context of a court system that has limited time and resources to afford all civil disputants any and every

reveals the presence of only one plaintiffs' attorney and one judge who was appointed to the bench by a Democrat. Defense lawyers, former prosecutors, and Republican-appointed judges (a good number of whom clerked for Chief Justice Rehnquist) dominate the committee. 
procedural opportunity they might wish to enjoy. In time, perhaps, like all historical regimes, procedure's empire of ordered dominance too will come to an end. 